10. Chemosensory Function in Congenitally Blind or Deaf Teenagers / Guducu C. et. al. // Chemosensory Perception. 2015. Vol. 9, Issue 1. P. 8-13. doi: http://doi.org/10.1007/s12078-015-9199-2

11. Ward J., Meijer P. Visual experiences in the blind induced by an auditory sensory substitution device // Consciousness and Cognition. 2010. Vol. 19, Issue 1. P. 492-500. doi: http://doi.org/10.1016/j.concog.2009.10.006

12. Pasqualotto A., Proulx M. J. The role of visual experience for the neural basis of spatial cognition // Neuroscience \& Biobehavioral Reviews. 2012. Vol. 36, Issue 4. P. 1179-1187. doi: http://doi.org/10.1016/j.neubiorev.2012.01.008

13. Deen B., Saxe R., Bedny M. Occipital Cortex of Blind Individuals Is Functionally Coupled with Executive Control Areas of Frontal Cortex // Journal of Cognitive Neuroscience. 2015. Vol. 27, Issue 8. P. 1633-1647. doi: http://doi.org/10.1162/jocn_a_00807

Дата надходження рукопису 10.05.2018

Сасіна Ольга Сергіївна, аспірант, кафедра гігієни та екології № 1, Харківський національний медичний університет, пр. Науки, 4, м. Харків, Україна, 61022

E-mail: ysatik83@ukr.net

Коробчанський Володимир Олексійович, доктор медичних наук, професор, кафедра гігієни та екології №1, Харківський національний медичний університет, пр. Науки, 4, м. Харків, Україна, 61022

UDC 616.891:314.72:159.9.072:347.157

DOI: $10.15587 / 2519-4798.2018 .139783$

\title{
ADJUSTMENT DISORDERS OF CHILDREN PATIENTS FROM INTERNALLY DISPLACED FAMILIES
}

\author{
(C) O. Samoilova, V. Ponomariov
}

У статті наведені дані щзодо вивчення розладів адаптації у дітей з сімей вимушених переселенців. Метою даного дослідження було визначення клінічних особливостей розладів адаптаиії у дітей із сімей вимушених переселениів.

Матеріали та методи. Було обстежено 66 дітей із родин вимушених переселенців з ознаками РА віком

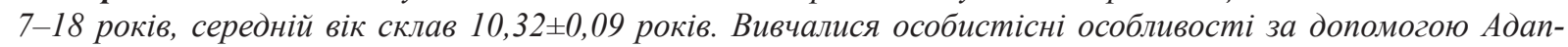
тованого модифікованого варіанту дитячого особистісного опитувальника Р. Б. Кеттелла (адаптація Е. М. Александровської, I. Н. Гільямевої, 1993), показники тривоги за допомогою Шкали ситуативної та особистісної тривожності Ч. Д. Спілберга та Ю. Л. Ханіна (2007), показники агресії та аутоагресї̈ за допомогою Методики діагностики показників та форм агресії Л. Басса та А. Даркі» (адаптаиія О. Осницького, 2008).

Результати. Отримані дані свідчать про складність та різноманітність клінічної картини розладів адаптації у зазначеної категорії пацієнтів. Визначені порушення емоційно-вольової, ціннісно-мотиваційної та когнітивної сфер у вигляді відособленості, холодності, ригідності та відчуженості, жорстокості. Констатовано низьку активність у встановленні та збереженні контактів з оточуючими. Виявлено високі показники тривожності, наслідком чого є присутність тривожних станів, невротичних конфліктів, емоиійних і невротичних зривів, психосоматичних розладів $і$ захворювань. Також виявлено схильність до агресії та аутоагресії, схильність використання фізичної сили та агресивності до інших осіб, запальність та грубість. Доведено залежність формування високого рівня агресивності від наявності у дітей з РА із родин вимушених переселенцівфізичної, непрямої та вербальної агресії, високого рівня індексу ворожості від проявів образи та підозрілості, агресивної мотивованої діяльності від фізичної та вербальної агресіі роздратування.

Висновки. Розлади адаптації у пацієнтів дитячого віку з сімей вимушених переселенців є актуальною проблемою сучасної психіатричної науки. За отриманими результатами зроблено висновок про необхідність подальшого більш глибокого вивчення РА з метою уточнення клінічних особливостей діагностичних критерїв і міменей психотерапевтичної корекції вищезазначених розладів

Ключові слова: розлади адаптації, клінічна картина, вимушені переселенці, діти, особистість, тривога, агресія

\section{Introduction}

For the past several decades adjustment disorders (AD) became more common in psychotherapeutic practice $[1,2]$. In the past decade the notion of "AD" became more common in psychiatry as well $[3,4]$. This diagnostic criterion was first mentioned in DSM-III and later was elaborated in the following classifications of illnesses [6, 7]. In ICD-10 adjustment disorders were 
classified as stress-induced disorders $[8,9]$ and in DSMIV they have their own category with emotional stress as the key pathogenic agent [10]. DSM-III-R defines AD as a disadjustment response to psychosocial stress with the onset of symptoms within 3 months of the stressor. The disorder usually ceases to manifest itself soon after the stress influence stops or after reaching a new (higher) adjustment level.

The development of ADs can be contributed by the individual's experience in local combat areas (this situation is characteristic of a large cross section of people in our country for the past few years); in this case the stress serves as a trigger for emergence and development of a number of mental disorders, primarily the AD [11].

\section{Case presentation}

At present a lot of researchers identify plenty of personal factors that contribute to the development of various psychological disorders as a response to stress: personal traits (low stress resilience, nihilism, anxiety, social alienation, etc); the development level of psychological defense mechanisms and the presence of the stress resistance strategy; the presence or lack of social support; the individual's assessment of the stress event its negative assessment or exaggerated danger have a greater effect on the body) [12].

The identified risk factors show that the development of AD is largely influenced by genetic factors; the individual's ability to adjust to the environment; person's social skills; the capacity for problem solving and identifying ways of coping with the crisis. The study with children identified constituting factors capable of developing $\mathrm{AD}$ in future: regular changes of the place of residence; social background (the extremes, such as poverty or affluence, make a difference); emergencies (catastrophes, military hostilities), or traumatic events, etc. [13].

Numerous foreign researchers posit the immense variety of clinical picture of different patients [15, 16], further complicating the AD diagnosis [13]. The literature describes clinical forms with the dominating psycho vegetative and asthenic disorders [17-20]; ADs that have dominating anger, aggressive reactions, negativity, behavioral disorders, etc. in their clinical picture. However, researchers also identify the presence of psycho pathological symptoms and associated manifestations of the vegetative dysfunction syndrome [21, 22].

It is noted that different patients have different and varying extents of adjustment disorder manifestations and levels. The usual symptoms include the anxiety and/or depressive syndromes with motivational disorders $[23,24]$.

\section{Aim of research}

The aim of the present research was to identify clinical peculiarities of adjustment disorders in children from IDP families.

\section{Materials and methods}

The survey examined 66 children with AD signs from IDP families aged $7-18$, the average age was $10.32 \pm 0.09$ years old. The study was conducted at the ward of Lysychansk Mental Clinic, in Lysychansk in 2014-2016. Out of the total number of children with AD from IDP families there were 32 children diagnosed with prolonged depressive reaction induced by AD (F43.21) and 34 children diagnosed with mixed anxiety and depressive reaction (F43.22). The characteristics of the examined patients are presented in Table 1.

Table 1

Characteristics of children from IDP families that have AD manifestations (abs., $\mathrm{X} \pm \mathrm{m}_{\mathrm{p}}$ )

\begin{tabular}{|c|c|c|c|}
\hline \multirow{2}{*}{ No } & Groups of children & \multicolumn{2}{|c|}{ IDP children with AD } \\
\cline { 3 - 4 } & & Abs & $\mathrm{X} \pm \mathrm{m}_{\mathrm{p}}$ \\
\hline 1 & boys & 31 & $10.39 \pm 0.13$ \\
\hline 2 & girls & 35 & $10.25 \pm 1.60$ \\
\hline 3 & children aged 7-10 y. o. & 25 & $10.55 \pm 0.16$ \\
\hline 4 & children aged 11-14 y. o. & 24 & $10.12 \pm 0.13$ \\
\hline 5 & children aged 15-18 y. o. & 17 & $10.26 \pm 0.17$ \\
\hline 6 & rural children & 34 & $10.22 \pm 0.12$ \\
\hline 7 & urban children & 32 & $10.42 \pm 0.13$ \\
\hline 8 & Total & 66 & $10.32 \pm 0.09$ \\
\hline
\end{tabular}

We have used clinical psychopathological, patho-psychological methods as well as statistical methods of processing the obtained data. The patho-psychological methods consisted of using R. B. Cattell's"'Children's Personality Questionnaire (CPQ)" (adjusted by E. M. Aleksandrovska, I. N. Giloasheva, 1993), "Spilberg-Khanin Situational and Personal Anxiety Scale" (2007), "BussDurkee Hostility Inventory (BDHI)" (adjusted by O. Osnytskyi, 2008). The child's personal file was augmented by information from medical and pedagogical documents, interviews with the parents, teachers and caregivers. In the survey each child or his/her parents signed an agreement to participate in the clinical survey. Each surveyed child, as well as his/her parents, was informed in advance about the aims and methods of the survey.

Statistical processing was carried out using the Student's test and the Fisher's ratio test.

\section{Results}

The examined children demonstrated the signs of visible anxiety and depressive syndromes with the manifestation of motivational disorders and vegetative dysfunction. Their most frequent complaints included:

a) signs of the anxiety syndrome: anxious mood; the feeling of being unable to cope with life situations; reduced level of daily functional activity; fears and concerns; the feeling of threat and increased tension; irritability; weenieness; "bad feelings"; the fear of anticipated unpleasant events, etc;

b) manifestations of the depressive syndrome: depressed mood; low spirits (even melancholy); fewer regular interests, desires and views; pessimistic thoughts; 
blames against oneself and the others for being unable to influence the events; considerable mental and physical exhaustion, low concentration and attention level, deterioration of memory, loss of any interests; having a hard time starting anything and "pulling oneself together"; the need to use willpower to do mundane daily tasks; difficulty with making decisions and seeing them through; sometimes - irritability, hypochondria, phobias;

c) motivational manifestations: considerable fatigue and weakness, disrupted diet routines (absence of appetite or the opposite), sleeping disorders (hard time falling asleep, light sleep, waking up frequently, nightmares, etc); decline in academic progress and professional activity, etc.;

d) symptoms of vegetative dysfunction syndrome: constant fever, shivering, tachycardia, nausea, abdominal pain, undetermined internal pain, diarrhea or constipation, neuro-endocrine disorders, etc.

Based on the "Adjusted modified variant of R. B. Cattell's Children's Personality Questionnaire (CPQ)" (adjusted by E. M. Aleksandrovska, I. N. Giliasheva, 1993), we have identified emotional and volitional, value and motivational as well as cognitive disorders of examined IDP children with AD: detachment, coldness, rigidity and alienation, cruelty (Factor $\mathrm{A}-3.93$ ); irritability, emotionality and mental fatigue (Factor $\mathrm{C}-3.32$ ); sense of personal guilt and inadequacy (Factor $\mathrm{H}-3.70$ ); manifestations of depression, worry and negative premonitions (factor $\mathrm{O}-6.54$ ). The children demonstrate lack of interest in establishing and maintaining contacts with people around them (Factor $\mathrm{A}-3.93$ and $\mathrm{H}-3.70$ ), manifestations of anxiety and helplessness (Factor $\mathrm{C}-3.32$ and I - 4.33), expecting something bad to happen (Factor $\mathrm{H}-3.70$, and $\mathrm{F}-4.41$ ), anxiety and concern (Factor $\mathrm{O}-$ 6.58; $\left.\mathrm{Q}_{4}-6.41\right)$, acting chaotically and in disorganized manner (Factor $\mathrm{Q}_{3}-4.64$ and $\left.\mathrm{G}-4.41\right)$.

At the same time boys with AD from IDP families acted reserved, cold, detached (Factor A - 3.79 with boys and 3.87 with girls); more realistic and independent (Factor I - 4.24 - with boys and 4.42 with girls); lower social sensibility and accuracy (4.47 and 4.71 of the $\mathrm{Q}_{3}$ Factor for boys and girls respectively) and they found it easier to adjust (Factor $\mathrm{Q}_{4}-6.33$ and 6.53 for boys and girls respectively). Unlike boys, the girls were more emotionally unstable and excitable, neurotically exhausted (Factor $\mathrm{C}-3.19$ with girls and 3.45 with boys); inert and impatient (Factor D - 6.77 - boys, 6.19 - girls); demonstrated higher obsession levels in their behavior as well as dependence on others (Factor E - 5.93 - males; 5.48 - females); showed more caution (Factor F - 4.45 boys and 4.32 - girls), they were more shy and reserved (Factor $\mathrm{H}$ - 3.73 - boys and 3.62 - girls); as well as more prone to depression, gloomy mood and bad premonitions (Factor $\mathrm{O}-6.42$ and 6.72 for boys and girls respectively.

Based on "Spilberg-Khanin Situational and Personal Anxiety Scale" (2007) we identified in a large group of the examined IDP children with AD a moderate level of reactive anxiety $(33.3 \pm 2.7 \%)$ predominantly with males $(18.2 \pm 2.2 \%)$ and children of 11-14 y. o. (12.1 \pm $\pm 1.9 \%)$ and a high level of personal anxiety $(87.9 \pm 1.9 \%)$ predominantly with girls $(45.5 \pm 2.9 \%)$ and persons of $7-10$ and $11-14$ y.o. ( $33.3 \pm 2.7 \%$ and $31.8 \pm 2.7 \%$ ), that results in anxious states, neurotic conflicts, emotional and neurotic breakdowns, psychosomatic disorders and illnesses.

Based on "Buss-Durkee Hostility Inventory (BDHI)" (adjusted by O. Osnytskyi, 2008) the survey also identified high levels of aggression and hostility in children from IDP families: more prone to use physical force and aggression towards other individuals (physical aggression 87.71 \pm 0.56 ; indirect aggression $88.09 \pm 0.46$; overall aggression level $24.12 \pm 0.53$; overall aggressive motivation level - $24.89 \pm 0.11$ ), quick temper and rudeness (irritability index $69.35 \pm 0.46$ ), oppositional stance and negativity towards the surroundings (verbal aggression index 75.39 \pm 0.36 ; negativity index $82.18 \pm 0.74$ ), mistrust and cautiousness (suspicion index 75.86 \pm 0.46 ; hostility index $13.7 \pm 0.09$ ), constant pangs of consciousness (feeling of guilt index 93.29 \pm 0.50 ). The study demonstrated the correlation between the development of the high aggression level in children with AD from IDP families and their physical, indirect and verbal aggression (the correlation coefficient are $0.5820 ; 0.5616$; $0.4782 ; \mathrm{p}<0.05$ respectively); high hostility index associated with the manifestations of resentment and suspicion (correlation coefficient 0.7091 and 0.6352 ; $\mathrm{p}<0.05$ ); aggressive motivated activity associated with physical and verbal aggression (the respective correlation coefficients are 0.5654 and $0.4821 ; \mathrm{p}<0.05$ ) and irritability (correlation coefficient $0.6049 ; \mathrm{p}<0.05$ ).

\section{Discussion of the results of the study}

In our opinion, the situation that has developed in the east of our country has entailed a catastrophic growth of psychogenic disorders, including adaptation disorders. Forced migrants, refugees - this category of our country's citizens is growing every year. As a rule, people flee from the zone of armed conflict with whole families, including children. Changing the habitual way of life, the threat of life, the violation of family relationships - all this leads to a violation of the psycho-emotional sphere, personal reaction to the formation of personal disorders, which as a result may lead to an increase in aggression and autoaggression. The data obtained in our study confirm the violation of these indicators. As the armed conflict continues its development, the number of families displaced from this zone also sells to grow. The results of our study may be of interest to researchers who are engaged in similar problems. Children are in dire need of psycho-correction, in particular - in psychotherapeutic correction. Understanding the features of the clinical picture of adaptive disorders will help specialists competently build an algorithm of psychotherapeutic influence, namely, to determine the targets of psychotherapy.

In general, the data obtained by us agree with the data obtained by other researchers. Thus, Yu. A. Aleksandrovsky [1], O. S. Antipova [2] and A. V. Starik [4] in their studies of violations of mental adaptation also noted the presence of anxiety and aggression in persons with adaptation disorders, but they did not describe these conditions in children from families of internally displaced 
persons. Markova M. V. with co-authors [6] paid great attention to family work, and in our opinion further emphasis should be placed on the psychotherapeutic correction of children's adaptation disorders. L. O. Gerasimenko [12] and V. S. Miakotnykh [11] and his colleagues also, like us, noted personality traits in stress-induced disorders. N. A. Shifner, A. E. Bobrov, M. A. Kulygina [14], Z. I. Kekelidze [15], L. Grassi [17] noted various variants of anxiety and aggression arising from stress. Ukrainian researchers (B. V. Mikhailov [18], M. V. Markova [6], M. S. Korolchuk [22], D. A. Zhupanova [24]) devote sufficient time to studying the problem of mental disorders in stress conditions. The data obtained by us do not contradict the data obtained earlier by other researchers.

\section{Conclusions}

1. Based on the "Adjusted modified variant of R. B. Cattell's Children's Personality Questionnaire (CPQ)" (adjusted by E. M. Aleksandrovska, I. N. Giliasheva, 1993), the research identified disorders in the emotional and volitional, value and motivational, as well as cognitive spheres of the examined children with AD from IDP the families: isolation, coldness, rigidity and alienation, cruelty, irritability, emotional excitement and mental fatigue, manifestations of depression, anxiety and negative feelings.
2. The survey identified using "Spilberg-Khanin Situational and Personal Anxiety Scale" that a significant share of the examined children with AD from IDP families demonstrate moderate reactive anxiety and a high level of personal anxiety, resultingin anxious states, neurotic conflicts, emotional and neurotic breakdowns, psychotic disorders and ailments.

3. The survey identified high levels aggression and hostility, based on "Buss-Durkee Hostility Inventory (BDHI)", namely: the tendency to use physical force and being aggressive to others, lack of flexibility and rudeness, oppositional behavior and negativism in treating the environment, distrust and caution, persistent pangs of consciousness.

4. Therefore, the research findings prove the complexity and diversity of clinical manifestations of IDP children's adjustment disorders. Due to the military situation we have found ourselves in over the last couple of years, many of our countrymen with their entire families were forced to change their place of residence within the country, hence the issue of adjustment disorders in this particular group of people necessitates further detailed studies to document and specify clinical characteristics of diagnostic criteria and targets of psychotherapeutic correction of the aforementioned disorders.

\section{References}

1. Aleksandrovsky Yu. A. Sostoianie psikhicheskoi adaptasii i nevroticheskie rasstroistva. Moscow: GEOTAR-Media, 2012. $52 \mathrm{p}$.

2. Antipova O. S. Rasstroistva adaptatsii: sovremennye podkhody k diagnostike i terapii // Psychiatry and Psychopharmacotherapy. 2012. Issue 6. P. 18-23.

3. Aktualni problemy psykholohii v zakladakh osvity. Kryvy Rih: Vydavnychyi Dim, 2011. 343 p.

4. Starik A. V. Kharakterystyka dysotsiatyvnykh staniv p ry podolanni psykhichnoii travmy // Young Researcher. 2018. Issue 1 (53). P. 54-57.

5. European Psychiatric Association (EPA) guidance on post-graduate psychiatric training in Europe / Mayer S. et. al. // European Psychiatry. 2014. Vol. 29, Issue 2. P. 101-106. doi: http://doi.org/10.1016/j.eurpsy.2014.01.002

6. Markova M. V., Rosinskyi H. S. Porushennia zdorovia simiyi demobilizovannykh viiskovosluzhbovtsiv-uchasnykiv ATO: psykhopatolohichnyi, psykholohichnyi, psykhosotsialnyi i simeynyi vymiry problemy // Ukrainian Bulletin of Psychoneurology. 2018. Vol. 26, Issue 1 (94). P. 78-82.

7. Pierre J. M. The Borders of Mental Disorder in Psychiatry and the DSM // Journal of Psychiatric Practice. 2010. Vol. 16, Issue 6. P. 375-386. doi: http://doi.org/10.1097/01.pra.0000390756.37754.68

8. Mnogoosevaia klassifikatsiia psykhicheskikh rasstroistv v detskom i podrostkovom vozraste. Klassifikatsiia psikhicheckikh i povedencheskikh rasstroistv u detei i podrostkov v sootvetstvii s MKB-10. Moscow: Smysl, Saint-Petersburg: Rech, 2003.407 p.

9. Churkin A. A., Martiushov A. N. Kratkoe rukovodstvo po ispolzovaniiu MKB-10 v psikhiatrii i narkologii. Moscow: Triada-X, 2000. 232.

10. Kawa S., Giordano J. A brief historicity of the Diagnostic and Statistical Manual of Mental Disorders: Issues and implications for the future of psychiatric canon and practice // Philosophy, Ethics, and Humanities in Medicine. 2012. Vol. 7, Issue 1. P. 2-10. doi: http://doi.org/10.1186/1747-5341-7-2

11. Miakotnykh V. S., Torgashov M. N. Stress-indutsirovannye rasstroistva. Saint-Petersburg: MobiDik Ltd, 2015. 216 p.

12. Gerasimenko L. O. Psykhosotsialna dezadaptatsiia (suchasni kontseptualni modeli) // Ukrainian Bulletin of Psychneurology. 2018. Vol. 26, Issue 1 (94). P. 62-65.

13. Smulevich A. B. Psikhopatologiia lichnosti i komorbidnykh rasstroistv. Moscow: Medpress-Inform, 2009. 208 p.

14. Shifner N. A., Bobrov A. E., Kulygina M. A. Kliniko-dinamicheskaia kharakteristika rasstroistv adaptatsii u studentov. Collection of Papers. 2011. Vol. 18, Issue 4. P. 64-66.

15. Kekelidze Z. I. Klinicheskaia kartina psykhicheskikh rasstroistv, voznikaiuchikh pri chrezvychainykh situatsiiakh // Post-traumatic Stress Disorder. Rostov-on-Don, 2015. P. 60-75.

16. Svechnikov D. V. Rasstroistva adaptatsii u voennosluzhashchikh (klinika i diagnostika): Abstract's PhD thesis. SaintPetersburg, 2015. 18 p.

17. Psychosomatic characterization of adjustment disorders in the medical setting: Some suggestions for DSM-V / Grassi L. et. al. // Journal of Affective Disorders. 2007. Vol. 101, Issue 1-3. P. 251-254. doi: http://doi.org/10.1016/j.jad.2006.11.011 
18. Mikhailov B. V. Psikhogenno obuslovlennye narusheniia psikhicheskoi sfery v usloviakh chrezvychainykh situatsii // Ukrainian Bulletin of Psychoneurology. 2015. Vol. 23, Issue 2 (83). P. 71-75.

19. Jager M., Frasch K., Becker T. Adjustment disorders -nosological state and treatment options // Psychiatrische Praxis. 2008. Vol. 35, Issue 5. P. 219-225. doi: http://doi.org/10.1055/s-2007-986289

20. Psychosomatic characterization of adjustment disorders in the medical setting: Some suggestions for DSM-V/ Grassi L. et. al. // Journal of Affective Disorders. 2007. Vol. 101, Issue 1-3. P. 251-254. doi: http://doi.org/10.1016/j.jad.2006.11.011

21. Miroshnik I. M., Gavrilin E. V., Mikhailov B. V. Informatsionno-energenitcheskii yazyk mezhlichnosnogo vzaimodeistvia: Intern. Conf. Mat. // Informational Energy of the Third Millennium. Kyiv-Kryvyi Rih, 2003. P. 128-130.

22. Korolchuk M. S., Korolchuk M. V., Myronets S. M. Psykholohichni osoblyvosti viddalenykh naslidkiv stresohennykh vplyviv [Psychological peculiarities of remote consequences of stress-generating influences]. Kyiv: Kyiv National University of Commerce, 2014. 276 p.

23. Kasper S. SOA03-01 - Understanding and treating depression // European Psychiatry. 2012. Vol. 27. P. 1. doi: http:// doi.org/10.1016/s0924-9338(12)75663-8

24. Zhupanova D. A. Uluchshenie komplaensa u patsientov s depressiiami (kompleksnaia sistema terapii i otsenka ee effektivnosti) [Better compliance of patience with depressions (comprehensive therapy system and assessment of its effectiveness)]. Ukrainian Bulletin of Psychoneurology. 2015. Vol. 23, Issue 3 (84). P. 68-73.

Дата надходження рукопису 29.05.2018

Olena Samoilova, Assistant, Department for Psychiatry, Narcology, Neurology and Medical Psychology, V. N. Karazin Kharkiv National University, Svobody sq., 6, Kharkiv, Ukraine, 61022

E-mail: exses@email.ua

Volodymyr Ponomariov, MD, Professor, Head of Department, Department for Psychiatry, Narcology, Neurology and Medical Psychology at V. N. Karazin Kharkiv National University, Svobody sq., 6, Kharkiv, Ukraine, 61022 E-mail: v.i.ponomaryov@ukr.net

УДК 615.387:615.072+612.119+615.077+606

DOI: 10.15587/2519-4798.2018.138222

\section{ПРОГНОСТИЧНА ОЦІККА РІВНЯ КРІОЧУТЛИВОСТІ ГЕМОПОЕТИЧНОЇ ТКАНИНИ ПУПОВИННОЇ КРОВІ ЗА МАРКЕРАМИ АКТИВНОСТІ ПРООКСИДАНТНИХ ПРОЦЕСІВ}

\section{(C) Т. О. Калиниченко}

Мета. Дослідити зв'язок рівня кріочутливості трансплантата гемопоетичної тканини (ГТ) пуповинної крові (ПК) людини за показниками втрати гранулоцитарно-макрофагальних клітин-попередників гемопоезу (ГМ-КПГ) з рівнем активності прооксидантних прочесів у цільній крові до початку ї̈ кріоконсервування. Методи дослідження. Кріоконсервування виділеної фракиії ядровмісних клітин ПК здійснювали методом повільного заморожування під захистом кріопротектора диметилсульфоксиду у кінцевій концентраціі $5 \%$ Втрату ГМ-КПГ визначали за різницею загального вмісту колоній та кластерів до кріоконсервування та після відтаювання зразка в короткостроковій культурі тканини. Активність прооксидантних процесів у ПК досліджували за біохімічними маркерами продуктів пероксидаџї ліпідів (ПОЛ), щзо визначали спектрофотометричним методом за концентрацією субстратів (ізольованих подвійних зв 'язків - ІПЗ), проміжних (дієнових, триєнових, оксодієнових кон'югатів - ДК, ТК, ОДК, відповідно) та кінцевих продуктів типу основ Шиффа (ШО) для нейтральних ліпідів та фосфоліпідів. Аналіз даних здійснений за моделями аналітичного групування, регресійного аналізу, взаємної спряженості.

Результати. Продемонстровано, щзо рівень кріочутливості ГТ ПК за втратою ГМ-КПГ має прямі кореляційні зв'язки з показниками активності ПОЛ (від середнього до високого рівня значущості). За умови високих рівнів показників ПОЛ в ПК до початку кріоконсервування істотно підвищується відносний ризик (ВР) втрати ГМ-КПГ. Зокрема, у разі пероксидації фосфоліпідів ВР складає: для ІПЗ - 5,29; 95 \% ДІ:

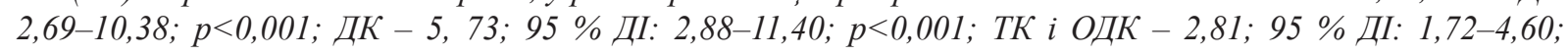
p<0,001, ШО - 1, 92; $95 \%$ ДІ: 1,16-3,18; $<<0,01$, відповідно.

Висновки. Оцінка рівня активності прооксидантних процесів у ПК з використанням біохімічних маркерів іщее до початку процедури заморожування має иінність у зв 'язку з можливістю створення раннього прогнозу кріочутливості ГТ, що може бути корисним для вибору тактики кріоконсервування

Ключові слова: гемопоетична тканина пуповинної крові, кріочутливість, перекисне окислення ліпідів, гранулоцитарно-макрофагальні клітини-попередники гемопоезу, низькотемпературні банки пуповинної крові 